\title{
MEASURING AND MODELLING FARM LEVEL SUSTAINABILITY
}

\section{Edward MAJEWSKI}

\author{
Warsaw University of Life Sciences, Poland
}

\begin{abstract}
In the paper, an approach to measure farm level sustainability with the Synthetic Farm Sustainability Index (SFSI) is presented. SFSI is composed of five partial sustainability indexes based on 56 parameters describing different aspects of farms organization and functioning. The index, calculated for the sample of 120 Polish farms, was used to measure the state (static sustainability) and effects of possible improvements (dynamic sustainability) in the farming system. The results of the analyses show significant differences in the sustainability level between the farms in the sample, as well as the potential for increasing SFS. The increase of the synthetic sustainability index can be achieved by means of farm investments, but also low-cost activities that improve environmental performance and generate positive social effects without undermining economic viability. It was also found out, that larger size, intensive farms can achieve high economic and environmental sustainability level if properly managed.
\end{abstract}

Keywords: farm, sustainability

\section{Introduction}

The concept of "Sustainable Development" is multidimensional, and sustainability can be measured on various levels, in space and time. This provides a wide field for the search of methods of measuring "sustainability", which are addressed to different sustainability aspects.

Initially, this was the consequence of the 1992 Conference in Rio de Janeiro, resulting from the need to create a set of sustainability measures and indicators to monitor the progress of the implementation of this concept on the global and individual country level. The sustainability indicators "were perceived as key tools in achieving the goals of Sustainable Development established in Agenda 21" (Rigby, Howlett and Woodhouse, 2000). It seems that the continuously appearing new proposals of "sustainability indicators" have significantly affected the popularisation, understanding and increased acceptance level of the "Sustainable Development" concept, which for many years was associated with a correct, but relatively abstract, peculiar philosophy. Development of sustainability indicators strongly supports the opinion of D. Panell, who presents the view that Sustainable Development is a "well-defined and measurable concept" (Pannell and Shilizzi, 1997). It is certain that the achievement of the present status of the "Sustainable Development" concept on a global scale would not be possible without the progress made in the methods of measuring "sustainability".

The list of indicators available for evaluating "sustainability" is very long. Selected examples presented below differ in their construction, scope and potential applications:

$\square$ Indicators such as Adjusted Net Savings (The World Bank 2004), Green National Product (OECD, 1996) and Genuine Savings (Hamilton, Atkinson and Pearce, 1997), Index of Sustainable Economic Welfare - ISEW, and the Genuine Progress Indicator - GPI (Cobb et al., 1995; Anielski and Soskolne, 2002; Venetoulis and Cobb, 2004; Gil and Śleszyński, 2000) that originate from traditional measures of economic development - the Net National Income or the Gross Domestic Product which insufficiently depict the social and environmental costs of human activity in national accounts.

$\square$ Sets of indicators proposed to measure different sustainability aspects: Indicators of Sustainable Development (social, environmental, institutional and economic) proposed by the UN Commission on Sustainable Development (2001), the Eurostat Sustainable Development Indicators (SDIs) presented in 10 themes $^{1}$ (Eurostat 2010), indicators to monitor Sustainable Development in Poland (Borys (edit.) 2005).

$\square$ Indicators related to environmental sustainability: the OECD Environmental Indicators² (OECD 2001), the Environmental Performance Index (EPI) (Esty et al, 2006; Esty, Boyd, 2006), Environmental Sustainability Index (ESI) proposed by the World Economic Forum (World Economic Forum, 2002)3, Ecological Footprint (Wackernagel and Rees, 1996) and Living Planet Index (LPI) (Loh, 2002).

\section{Sustainability Indicators for Agriculture}

The paradigm of "sustainability" equally refers to agriculture and other fields of economy, or, more generally, areas of human activity. Much like in the case of the superior concept of "Sustainable Development", the discussion on "Sustainable Agriculture" holds many definitions and interpretations of this concept. The numerous attempts to define "Sustainable Agriculture" clearly show that the definitions are derived from various perspectives. In social categories, the main premise for consideration, which strongly accents the ethical point of view, is the "satisfaction of the needs of the present generation without lowering the prosperity of future generations" from the Brundtland Report. The social and natural aspects of "Agricultural Sustainability", as

\footnotetext{
In the document,"Measuring progress towards a more sustainable Europe..." published by the EU Commission in the year 2001, 63 indicators were presented. In February 2005 European Commission approved the set of 155 indicators (SDIs) used to monitor the EU Sustainable Development Strategy (EU SDS) reported by Eurostat every two years in ten themes: Socio-economic development, Sustainable consumption and production, Social inclusion, Demographic changes, Public health, Climate change and energy, Sustainable transport, Natural resources, Global partnership, Good governance (http://epp.eurostat.ec.europa.eu/portal/page/portal/sdi/indicators)

2 The Core Set of about 50 indicators reflecting the main environmental concerns (climate change, ozone layer depletion, air quality, waste, water quality, water resources, forest resources, fish resources, biodiversity) in OECD.

3 A measure of the overall progress towards environmental sustainability, developed for 142 countries. The ESI scores are based upon a set of 20 core indicators, each of which combines two to eight variables for a total of 68 underlying variables.
} 
well as its long-term significance, are strongly emphasised by Francis and Youngberg, who believe that "it is a philosophy based on human goals and on understanding the long-term impact of our activities on the environment ..." (Francis, 1990). Runowski (2007) highlights ethical aspects of farming in line with the sustainability paradigm and a need of balancing environmental, economic and ethical objectives.

For many years, $O E C D$ has been presenting particular activeness in the construction and popularisation of environmental sustainability indicators. In the conceptual sense, the frames for the set of environmental indicators are determined by the PSR (pressure, state, response) model and distinction of 15 issues concerning natural environment, considered as the main challenges facing the OECD member states (OECD, 2001, 2002).

A different collection of indicators, strongly oriented towards environmental issues, is recalled by A. Faber from the description of the ELISA project, which attempted to "apply the OECD model in the selection of indicators for the evaluation of agriculture in the entire $\mathrm{EU}$, member states and regions" (Faber, 2001).

For two main reasons, the proposal of Woodhouse and co-authors is worth noting as well. In their model of sustainability indicators, they applied the combination of two schemes: FESLM, with the distinction of five pillars of sustainability, and SRL, the approach to the analysis of relations between livelihoods and the use of natural resources.

The ability to use the indicators in the analysis of the impact of the agricultural policy on agricultural sustainability was presented with the example of Scottish agriculture by Thomson and Snadden, using their own collection of indicators (Thomson and Snadden, 2001).

In order to compare the systems of agricultural production of new EU member states, A. Cristoiu applied sustainability indicators and adopted the methodology created by the Columbia University ${ }^{4}$ used by Gonzalez-Lafe and M. Palmero for the 15 previous European Union member states (Cristoiu, 2005). Because of the selection of the variables used in the analysis and application of the average parameters describing the dominating systems of production in compliance with the FADN classification, the comparison refers to the regional level. K. van Calker assessed the sustainability for dairy farms, subsequently using it as an objective function in the optimisation model (van Calker, 2005). He distinguished attributes equal to significant issues or aspects for each of the basic sustainability areas (dividing the social sustainability area into internal and external), and subsequently selected indicators adequate to the measurement of selected phenomena.

Sustainability indicators are used for comparisons of different farming systems and production methods (Fernandes and Woodhouse, 2008; Bockstaller et al., 2009; Darnhofer et al., 2011). Van der Welf and Petit (2002) present a review of indicators of environmental impact that may be based either on farmer production practices ("means-based") or on the effects these practices have ("effect-based") in terms of the state of the farming system or emissions to the environment: the farmer sustainability index (Taylor et al., 1993) that takes into account 33 farmer production practices for producing cabbage evaluated with positive or negative scores summed to a farmer sustainability index (FSI); Indicators of Farm Sustainability (IFS) (Vilain, 1999) - a method used for the evaluation of agroecological, socio-territorial and economic sustainability of different farm types in France, which assigns scores to farmer production practices and farmer behaviour; methods based on the life cycle analysis (LCA) (Biewinga and van der Bijl, 1996; Audsley et al., 1997; Rossier, 1999); Ecopoints proposed by Mayrhofer et al. (1996), which assign scores to farmer production practices and landscape maintenance; as

Columbia University (2002) for Benchmarking National Environmental Stewardship well as Agro-ecological indicators (AEI) (Girardin et al., 2000) to evaluate the effects of farmer production practices on components of the agroecosystem (after Van der Welf and Petit, 2002).

\section{The Synthetic Farm Sustainability Index (SFSI)}

The Synthetic Farm Sustainability Index (SFSI) presented in this paper corresponds with a general model RAEP: "Resources - Actions - Effects Pressures" (fig. 1), which in a simplified way replicates the farm functioning mechanism (Majewski, 2008). This model assumes that each farm, from the viewpoint of the existing state of sustainability, is subjected to equal "pressures" (forces of change) from the economic policy or social demands. Therefore, it is possible to state that regardless of the impact orientation of the forces of change (beneficial or unbeneficial to the improvement of farm sustainability) existing at a given time or foreseeable in the future, every farm operates under the same macroeconomic conditions, apart from the possible diversities resulting from its geographic location. The adaptation of the farmers to these conditions, with a defined method of using their resources, determines the results of their operations constituting the level of sustainability criteria fulfilment and potential ability of the farm for longterm sustainability and development.

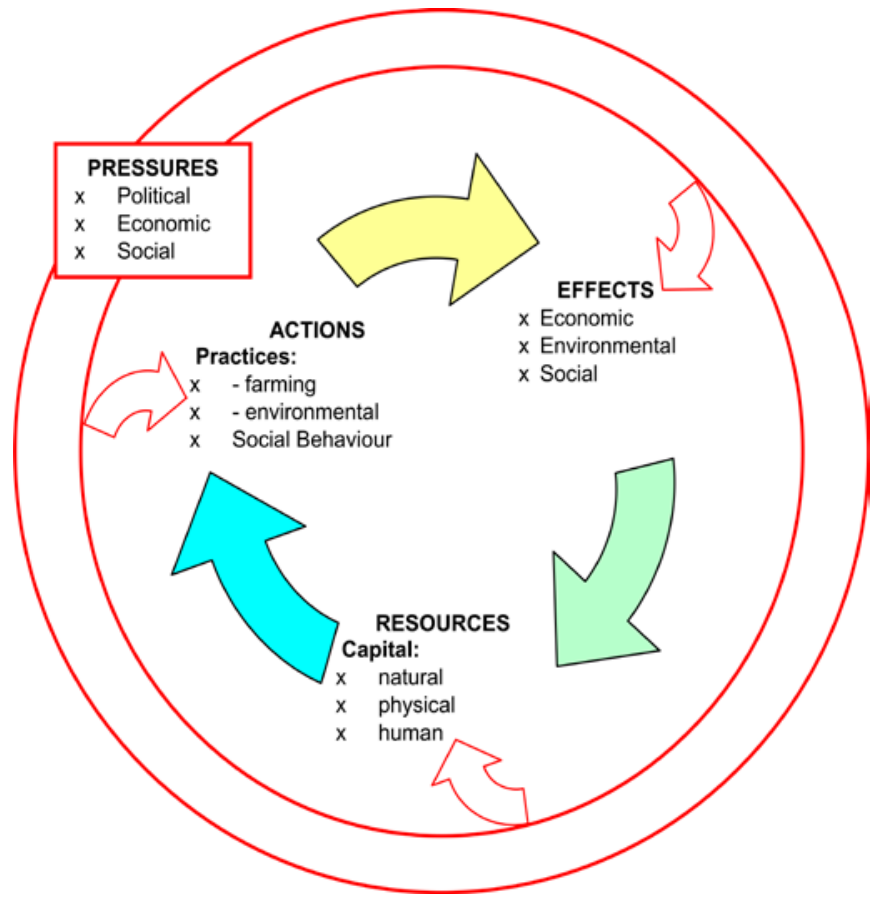

Figure 1 Model Resources - Actions - Effects - Pressures Source: Majewski, 2008

The desired results of the system's (farm's) operations can be perceived in the categories of the following effects: economic (long-term economic viability), environmental (reduction of threats to the natural environment) and social. The latter might be assessed from the viewpoint of general societal benefits, but also implications to the farmer and the farmer's family as members of the social community. The dimensions and quality of the farm resources, as well as the ability (methods) of using them properly to achieve effects through the application of defined agricultural and environmental practices as well as social behaviour, determine the volume of these effects. The actions are subjected to certain limitations due to the "pressure" of the macroeconomic and social conditions, but mainly depend on the volume and quality of the resources held by the farmers. 
In the short term, the operations of the producer are determinants, meaning that in the course of the decision-making process, all decisional problems, which can be attributed with the properties of uncertainty conditions, are solved by the lack of decisions (actions) or choices made in the same manner as under certainty conditions. Since the "pressures" are recognised or expected in the near future, they compose a collection of permanent, exogenous factors shaping the management conditions. From the time perspective of the sustainability scale, this provides the operations of the system with a static nature in a short time. In a static depiction, sustainability is a certain measurable state, shaped by the cooperation of the three basic elements of the RAEP model: Resources - Actions - Effects. By using the acquired knowledge, including that on the existing forces of change ("pressures"), it is possible to foresee the future chances of the system's (farm's) sustainability.

In the long term, the complex farm system may be subjected to evolutional transformation to a various extent, with properties of improvement (sustainability increase) or degradation (sustainability reduction). In time, these changes occur in an unending cycle, since the existing resources and actions determine current effects, but in the long term, the effects of the operations, mainly but not exclusively economic, determine the ability to maintain or expand the existing state of resources. This in turn conditions further actions and effects. If in time, simultaneously, new "pressures" should appear, the previous evaluations of the sustainability state may change.

Therefore, the construction of the farm sustainability index refers to the identified sustainability state, but on its basis, we are able to draw conclusions on the possibilities of the improvements for the system, i.e. opportunities to increase or threats of reduction of the sustainability level. This inference requires the evaluation of the possibilities of introducing changes in the method of using the farm's resources by the farmer, and may also include the foreseen influence from the "forces of change". This brings the possibility to determine the future, probable sustainability states, providing the analysis with a dynamic nature.

\section{Methodology}

The SFSI was calculated with the use of the Multiple Weight Method for the sample of 120 farms of more than two hectares of agricultural land. The selection of farms for the sample was made with the use of stratified random sampling method. Data for the FSI calculation were collected through direct interviews conducted by agricultural advisors from respective regions. The SFSI estimated for a specific point in time represents, according to B. Hill, the static sustainability.

In the second stage of the study, seven farms representing different production orientations were selected for more detailed analyses and planning for changes in farms' organization and agricultural practices that should allow increasing the sustainability level. Possible improvements were discussed with farmers. The changes, which could have an impact on financial results, were modelled with the use of farm optimization model. The SFSI calculated after introducing possible improvements reflects the Hill's concept of the dynamic sustainability.

The set of 150 parameters to measure the sustainability of farms was taken into consideration at the initial stage. In some cases, the individual parameters were processed into more aggregated values. Next, a panel of Polish and foreign experts with unquestionable knowledge on agricultural sustainability and farm management performed an initial verification of the list. This allowed limiting the final number of parameters to 56 variables. The experts also expressed their opinions on the significance of individual parameters during the discussions about the usefulness of individual criteria. The parameters applied as variables in the calculation of the index have been grouped into five categories of variables (table 1).

While the recognition of the three basic sustainability pillars (economic viability, social acceptance and environmental friendliness) is obvious, the addition of the two other categories is debatable. However, it has been assumed that both the organisation of production processes and the quality of production space are endogenous variables, which strongly mark the nature of farming activities, and simultaneously deepen the analysis of "agricultural sustainability" at the farm (production system) level. The group of variables concerning the organisation of production and management covers the parameters describing agricultural practices. These are "actions", which significantly influence mainly the level of economic and environmental effects. Similarly, the quality of the production space („resources“) of farm has significant impact mainly on of economic effects.

The multiple weight method (MWM) applied to the calculation of the sustainability index is a version of summarised spot methods of the general evaluation of both quantitative and qualitative phenomena. The MWM was initially used to determine Polish regions particularly predestined for organic production (Radecki et al., 1999). The method was adequately modified for the purpose of calculating the sustainability index, grouping the variables into five sustainability categories and limiting the "weighing" procedure to two levels. In compliance with the adopted model, the absolute value of each calculation parameter (the qualitative properties were quantified) was indexed in range between 0 (least beneficial value) and 1 (most beneficial value), and multiplied by the weight appointed to the individual properties in scope of individual categories of variables. The sum of the results of multiplications composes the partial sustainability index for each category. The second stage of calculations sees another appointment of weights to partial indicators (group weights), and the sum of the results determines the Synthetic Farm Sustainability Index. In every case, the sum of weights of the first and second level is equal to 1 . The initial calculation applies equal partial weights (in scope of an individual category) and group weights. However, it is possible to apply diverse weights to individual variables and partial indexes.

The procedure of indexing variables applies to different approaches, depending on the type of variable and its absolute values:

A. For continuous variables with an objectively indefinable minimum and maximum of a given property, the boundary values were assumed at the level of averages from $25 \%$ of the examined objects with the lowest absolute value of a given property and analogically from $25 \%$ objects with the highest value. Adequately, all objects with the property value below the average of the lowest values were assigned with the value of " 0 ", while the objects with the absolute value of this property above the average of the fourth quarter were assigned with the value of "1"5. This approach limited the impact of the outliers (e.g. a significantly larger arable area in individual farms) on the results of variable normalisations and was applied to the following variables: area of land, sales profitability, effectiveness of fixed assets, net income and disposable income per family member.

For example, the net agricultural income in the group of $25 \%$ farms with the lowest revenue had value in range of -14883 to +1831 PLN, while the highest revenues in $25 \%$ of the farms were at the level of 42214 to 271161 PLN. The average values in bottom and top quartiles were respectively -2 854 PLN and 94426 PLN. Fourteen farms in the sample had a financial result below the first of these averages (with assigned value of " 0 "), while 12 farms reached the net income higher than 94 thousand PLN (with assigned value of "1"). The value of the net farm income in other farms was linearly indexed to the range of $0-1$, depending on the volume of the income falling within the limits of the top and bottom average. 
Table 1 Set of variables used for constructing the Farm Sustainability Index (FSI)

\begin{tabular}{|c|c|c|c|}
\hline No. & Variable & No. & Variable \\
\hline \multicolumn{2}{|r|}{ Measures of economic sustainability } & \multicolumn{2}{|r|}{ Measures of social sustainability } \\
\hline 1 & Area of agricultural land & 13 & Level of education \\
\hline 2 & Dependence on social welfare & 14 & Likelihood of succession \\
\hline 3 & Share of credits repayment in personal income & 15 & Self-evaluation of farmer's affluence \\
\hline 4 & Instability of outputs & 16 & Household facilities \\
\hline 5 & Instability of income & 17 & Accessibility of social services \\
\hline 6 & Dependence on subsidies (\%) & 18 & Social capital \\
\hline 7 & Return on Sales (ROS) & 19 & Position in social hierarchy \\
\hline 8 & Effectiveness of fixed assets & 20 & Indicator of broad/narrow mindedness \\
\hline 9 & Net farm profit & 21 & Participation in training courses \\
\hline 10 & Utilized value of key machinery in \% & 22 & Natural infrastructure area \\
\hline 11 & Utilized value of farm buildings in $\%$ & 23 & Farm aesthetics \\
\hline 12 & Personal income per capita & 24 & Reading indicator \\
\hline \multicolumn{2}{|r|}{ Measures of environmental sustainability } & \multicolumn{2}{|c|}{ Organisation of production and farm management practices } \\
\hline 25 & Appropriateness of organic fertilizers application* & 37 & Appropriateness of crop rotation* \\
\hline 26 & Use of pesticides & 38 & Share of intercrops in rotation \\
\hline 27 & Domestic sewage management & 39 & Soil testing \\
\hline 28 & Solid manure storage potential & 40 & Appropriateness of agronomic practices* \\
\hline 29 & Liquid manure storage potential & 41 & Share of permanent grassland \\
\hline 30 & Waste utilization & 42 & Calcium fertilization \\
\hline 31 & Annual balance of phosphorus in the soil in $\mathrm{kg}$ of $\mathrm{P} / \mathrm{ha}^{*}$ & 43 & Seed dressing \\
\hline 32 & Annual balance of potassium in the soil in $\mathrm{kg}$ of $\mathrm{K} / \mathrm{ha}^{*}$ & 44 & Measures to support decision making on crop protection \\
\hline 35 & Annual balance of magnesium in the soil in $\mathrm{kg}$ of $\mathrm{Mg} / \mathrm{ha}^{*}$ & 47 & Livestock density \\
\hline 36 & Soil cover index* & 48 & Animal welfare \\
\hline \multicolumn{4}{|c|}{ Quality of production space } \\
\hline 49 & Soil quality index & 53 & Soil acidity \\
\hline 50 & Content of available Phosphorus in the soil & 54 & Threat of soil erosion \\
\hline 51 & Content of available Potassium in the soil & 55 & Number of plots of land \\
\hline 52 & Content of available Magnesium in the soil & 56 & Index of valorization of agricultural productive space ${ }^{* *}$ \\
\hline
\end{tabular}

* methodologies of calculation of indicators are presented in details in several publications: Wijnands, Verijken, 1992, Majewski, 2002, Majewski et al. 2002, Łabętowicz et al. 2003, Łabętowicz et al., 2004; ** Valorization of agricultural production space (Witek, 1981)

Source: Majewski 2008

B. For continuous values, with an objectively definable minimum and maximum, the indexation was conducted linearly for the entire scope of variability of a given property in the population. This assumes that the higher the value of the variable, the higher or the lower sustainability indicator is, depending on the nature of the variable. This concerns, for instance, such parameters as: area of ecological infrastructure - in scope of $0 \%$ (no sustainability) to $3 \%$ of arable area as the desired value (Majewski et al., 1997), balance of organic matter in soil (OMAB) - between $-0.15 \mathrm{~T} /$ ha (value of " 0 ") and $1 \mathrm{~T} /$ ha and above (value of "1"), balances of nutrients (NAB, PAB, KAB) - the optimal division was appointed between - 10 and $+10 \mathrm{~kg} / \mathrm{ha}$ (indexed value $={ }^{\prime \prime} 1$ "), assuming that the optimal zero value is practically difficult to achieve, and furthermore, the created balances are burdened with the estimation error.

C. In the case of other variables (continuous and non-continuous), three to six classes (intervals) of property value were determined individually for each parameter and assigned with subjectively defined values in scope of $0-1$.
Many of the principles concerning the indexation of the variables according to subjective evaluations can certainly be considered disputable. However, it seems that the expert knowledge of specialists from various fields, mainly agricultural sciences, used for this purpose was a sufficient foundation to consider these results as correct.

\section{The Synthetic Farm Sustainability Index (SFSI) - results}

The basic characteristics of the sample of 120 farms, for which the SFSI was calculated, is presented in table 2 .

The average value of the SFSI for the analyzed sample of farms is 0.52 (table 2) which only slightly exceeds $50 \%$ of the maximum value (1.0). Considering the strong diversity of agricultural farms in Poland, i.a. in terms of the scale of production, productivity of land or the level of technological advancement, it can be stated that it is moderately good and properly reflects the reality of Polish agriculture from the viewpoint of sustainability. However, the fact that almost half of the farms in the sample are in the group with 
Table 2 Characteristics of the sample of farms

\begin{tabular}{|c|c|c|c|c|c|}
\hline Item & Mean & Standard Deviation & Value minimum & Value maximum & Median \\
\hline Area of agricultural land in ha & 20.5 & 26.7 & 2.0 & 245.7 & 12.4 \\
\hline Area of permanent grassland in ha & 5.5 & 8.1 & 0.0 & 46.0 & 2.6 \\
\hline Number of fully employed (AWU)* & 2.2 & 0.8 & 0.5 & 4.6 & 2.0 \\
\hline Farmer's age (years) & 44 & 9.8 & 21 & 65 & 44 \\
\hline Index of soil quality & 0.9 & 0.2 & 0.4 & 1.7 & 0.8 \\
\hline Gross value of fixed assets in PLN/ha & 31,207 & 21,954 & 8,437 & 138,400 & 39,746 \\
\hline Depreciation of fixed assets in $\%$ & 73.6 & 17.2 & 19.2 & 99.7 & 84.1 \\
\hline Number of Livestock Units in LU & 85.7 & 78.8 & 0 & 471 & 78.9 \\
\hline Share of cereals in the cropping structure in \% & 73.7 & 24.2 & 0 & 100 & 78.5 \\
\hline Milk yield in litres/cow & 3,626 & 1,224 & 1,500 & 7,000 & 3,600 \\
\hline Mineral fertilization in NPK kg/ha & 132 & 75 & 0 & 286 & 133 \\
\hline Farm Net Income in PLN/ha & 1,623 & 2,812 & $-2,082$ & 13,214 & 860 \\
\hline
\end{tabular}

* own labour resources (farmer and family members living and working on farm) Source: Own study

Table 3 Synthetic Farm Sustainability Index in the sample of 120 farms

\begin{tabular}{|l|c|c|c|c|c|}
\hline $\begin{array}{l}\text { Sustainability } \\
\text { Indexes }\end{array}$ & Average & Standard deviation & Value minimum & Value maximum & Skewness \\
\hline Economic & 0.57 & 0.16 & 0.23 & 0.92 & 0.245 \\
\hline Social & 0.52 & 0.16 & 0.12 & 0.79 & -0.10 \\
\hline Environmental & 0.59 & 0.09 & 0.39 & 0.82 & 0.348 \\
\hline Organization and management & 0.44 & 0.14 & 0.16 & 0.71 & 0.099 \\
\hline Quality of production space & 0.50 & 0.25 & 0.13 & 0.94 & 0.424 \\
\hline FSI & $\mathbf{0 . 5 2}$ & $\mathbf{0 . 1 2}$ & $\mathbf{0 . 2 7}$ & $\mathbf{0 . 7 8}$ & $\mathbf{0 . 3 8 8}$ \\
\hline
\end{tabular}

Source: Own calculations

a sustainability index below average (the median value of 0.50 in the examined sample is closer to the average value than the entire population) should be considered rather pessimistic. It should be emphasized, however, that it is practically impossible to achieve the maximum value of the FSI (1.0) even in the case of a perfect farm not only because of imperfect farmer's decisions, but mainly due to competition between sustainability objectives (eg. economic and environmental) and thus unavoidable trade-offs.

The partial indexes calculated for individual sustainability areas as well as the SFSI significantly vary in the sample of farms. The highest average values of the environmental ( 0.59$)$ and economic (0.57) sustainability indexes give a reliable indication of the farms' prosperity and their impact on the natural environment. The lowest index was that for the area of "organisation

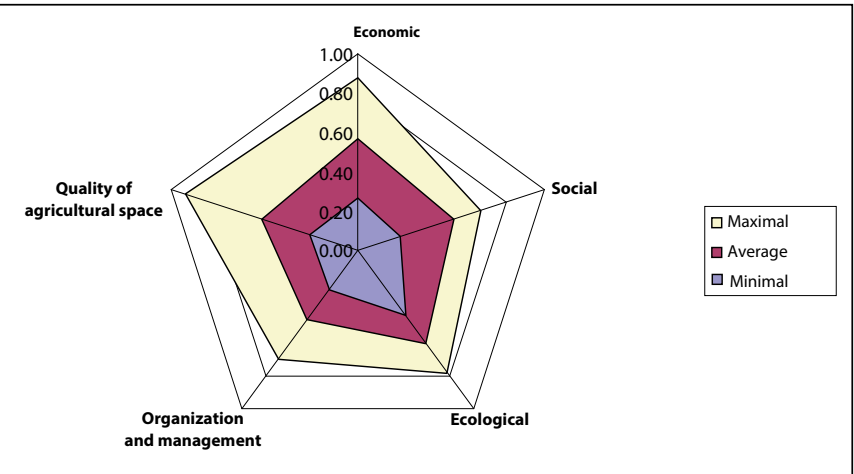

Figure 2 Minimal, average and maximal values of partial sustainability indexes in the analyzed sample of farms Source: own calculations and management" (0.44), which confirms the conclusions from the previous studies, suggesting unsatisfactory quality of agricultural practices of Polish farmers (Majewski, 2002). At the same time, the fact that this area is the subject of a rather easy improvement is optimistic. The correctness of agricultural practices most often depends exclusively on the decisions of producers, and in many cases, it does not require additional investment expenditures or a significant cost increases.

The index of "production space quality" also reached a relatively low level. However, in this case, in contrast to "organisation and management", the farmer is not capable of affecting individual components (e.g. soil quality). Moreover, improving the quality of the basic resource of agricultural farms (land) is a long-term and expensive process (e.g. soil nutrient availability, soil reclamation).

The synthetic index and the partial indices are all very variable and have significant discrepancy between the minimum and maximum values which is graphically illustrated in Figure 2 where the averages for the entire population, as well as minimum and maximum values of partial sustainability indexes confirmed in individual farms are presented.

The closer the shaded image on the web diagram is to the edge, the higher the index value. The closer to the diagram centre, the lower the sustainability level for the given area is. At the same time, the filling level of the polygon reflects the volume of the synthetic sustainability factor.

The increase of farm area is accompanied by a significant growth of the economic and social sustainability indexes (table 4).

Similarly the indexes for organisation and management, production space quality and the synthetic sustainability index increase, although the discrepancies between the extreme values are smaller. The index of 
Table 4 Sustainability indexes in farm size clusters

\begin{tabular}{|l|c|c|c|c|}
\hline \multirow{2}{*}{ Indexes } & \multicolumn{4}{|c|}{ Clusters of farm size in hectares } \\
\cline { 2 - 5 } & $<7.0$ & $\mathbf{7 . 1 - 1 5 . 0}$ & $\mathbf{1 5 . 1 - 3 0 . 0}$ & $>\mathbf{3 0 . 1}$ \\
\hline Economic & 0.42 & 0.54 & 0.61 & 0.73 \\
\hline Social & 0.40 & 0.49 & 0.57 & 0.66 \\
\hline Ecological & 0.54 & 0.56 & 0.54 & 0.54 \\
\hline Organization and Management & 0.35 & 0.44 & 0.47 & 0.55 \\
\hline Quality of agricultural space & 0.48 & 0.54 & 0.46 & 0.58 \\
\hline SFSI & $\mathbf{0 . 4 4}$ & $\mathbf{0 . 5 1}$ & $\mathbf{0 . 5 3}$ & $\mathbf{0 . 6 1}$ \\
\hline Coefficient of Variaiton & $27.2 \%$ & $26.1 \%$ & $20.9 \%$ & $14.2 \%$ \\
\hline
\end{tabular}

Source: Own calculations

Table 5 Sustainability indexes for the farms of different production orientation and production level intensity

\begin{tabular}{|c|c|c|c|c|c|c|c|}
\hline \multirow{2}{*}{$\begin{array}{l}\text { Production } \\
\text { orientation }\end{array}$} & \multicolumn{7}{|c|}{ Sustainability Indexes } \\
\hline & Number of farms & Economic & Social & Ecological & Organization and management & Quality of agricultural space & SFSI \\
\hline Arable & 5 & 0.52 & 0.46 & 0.53 & 0.44 & 0.59 & 0.51 \\
\hline Pigs & 28 & 0.57 & 0.54 & 0.54 & 0.45 & 0.60 & 0.54 \\
\hline - low-input & 15 & 0.49 & 0.53 & 0.52 & 0.41 & 0.57 & 0.50 \\
\hline - intensive & 13 & 0.63 & 0.55 & 0.55 & 0.49 & 0.62 & 0.57 \\
\hline Mixed & 28 & 0.45 & 0.46 & 0.51 & 0.39 & 0.49 & 0.46 \\
\hline - low-input & 15 & 0.37 & 0.36 & 0.53 & 0.28 & 0.35 & 0.38 \\
\hline -intensive & 13 & 0.53 & 0.58 & 0.50 & 0.51 & 0.65 & 0.55 \\
\hline Cattle & 46 & 0.60 & 0.51 & 0.54 & 0.42 & 0.40 & 0.49 \\
\hline -low-input & 15 & 0.51 & 0.46 & 0.53 & 0.31 & 0.28 & 0.42 \\
\hline - intensive & 14 & 0.73 & 0.58 & 0.56 & 0.60 & 0.56 & 0.60 \\
\hline Ecological & 5 & 0.56 & 0.49 & 0.62 & 0.60 & 0.61 & 0.58 \\
\hline Highly intensive & 21 & 0.76 & 0.67 & 0.67 & 0.59 & 0.73 & 0.69 \\
\hline
\end{tabular}

environmental sustainability stays at a very similar level. It should be noted that in each division, the synthetic sustainability factor holds a low level of variability of standard deviation in relation to the average, which proves the homogeneity of the selected farm groups, considering not only sustainability, but indirectly also their relation to their technical and economical nature.

Table 5 presents the farms according to the orientation of production, and additionally, according to the level of intensity of production. For comparison, the results for the highly intensive farms that may be considered as a "control group" were also presented. This group received farms with various production orientations (including fruit farms), with the common properties including a large scale and high intensity of production.

The SFSI in farms with defined production orientation (arable, pig, mixed and cattle) is at a similar level (between 0.46 and 0.54 ). The synthetic index is noticeably higher in ecological farms mainly due to the high environmental performance, as well as in the "control group" composed of the most intensive farms in the sample. Such farms can be considered as leading in Poland in terms of innovation, pace of technical progress implementation and economic results. Compared to the entire population, the farms in the control group hold a high level of the synthetic index and partial sustainability indicators proving that well managed, economically viable farms may provide also environmental benefits, comparably with ecological farms.

The growth of the intensity level entails improvement of the synthetic sustainability indicator as well as the partial indexes. This dependency is particularly visible in reference to economic sustainability, as well as organisation, management and production space quality.
The forming of the partial index of environmental sustainability deserves special attention. First of all, in contrast to other indexes, it is very similar in all farm groups, regardless of the production orientation and intensity level. Furthermore, the population's most intensive fruit farms and control group farms hold the highest environmental sustainability. This contrasts with the stereotype, often presented in Poland, on the "environmental friendliness" of traditional, low-input farms, particularly due to the level of mineral fertilisation and intensity of chemical crop protection. Actually, the determinant, from the viewpoint of the environmental effects of farming is the quality of the applied technologies and effectiveness of inputs, as well as equipping the farms with an environmental technical infrastructure, limiting the negative impact of farms and households on the environment.

\section{Modelling for sustainability}

Farms, like many other businesses, are dynamic organisations with longterm transformation processes. They may be induced by the signals from the external environment (market and macroeconomic), and caused by the decisions of farmers resulting from the changes of internal conditions (e.g. related to the family's life cycle) as well as individual aspirations.

In present times, external pressures, such as the liberalisation of agricultural trade, growing qualitative requirements, continuous technical and biological advancements, as well as the rise of the significance of the economy of scale, force the farmers to perform adequate adaptations serving the improvement of competitiveness and at least maintenance of the previous level of farm incomes. Simultaneously, particularly following 
Poland's accession to the European Union, in scope of the agricultural and environmental policies, the farmers face increasing expectations, as well as incentives to limit the negative impact on natural environment, active participation in the forming of biological diversity and rural landscape, or the improvement of animal welfare. The agricultural policy offers tools and financial resources supporting the desired transformation orientations, making it easier for the farmers to realize their own plans.

From the perspectives of both the agricultural policy and the social viewpoint, the expected effect of the changes to the organisation of agricultural farms should be the improvement of their sustainability levels. The algorithm for calculating the synthetic farm sustainability index was used to calculate the SFSI for the panel of seven farms, following the simulation of various activities which could be implemented by the farmers within improving their workspace. The potential impact of the possible changes in farm organisation on the value of the sustainability index was defined on the basis of model results (mainly in the area of economic sustainability), with application of the farm linear optimisation model. The results of the model, which assumed farm income as the objective function, also allowed for the partial assessment of the environmental effects. This was possible due to introducing adequate constraints into the model (e.g. maximum share of crops and species, minimum soil coverage, minimum organic substance balance). Also investments influencing the animal welfare and reducing different environmental hazards were planned. It was also assumed, depending on the characteristics of each farm in the panel, that there was a need for additional expenditures and costs to improve certain parameters of social and environmental sustainability, for example, natural ecological infrastructure, improvement of the agricultural farmyard aesthetics, training courses, reading, etc.

Planning for changes and modelling results allowed calculating a potential SFSI, which corresponds with the concept of dynamic sustainability. Several variants of changes in farms organization were considered, resulting in the increase of the SFSI (table 6).

Compared to the entire population, only the farm A reaches the SFSI in the base model below the average values, while other two farms ( $F$ and $\mathrm{G}$ ) represent a small group of farms with sustainability index clearly above the average. Each of the solutions increases the SFSI, while the improvement of the index was clearly more significant in farms with a low initial SFSI (approximately $50 \%$ in farms $A$ and D). This indicates a high possibility of increasing the sustainability level on many farms in Poland.

In all the cases, value of the partial indicators was the lowest in the base model, and the highest in the "Farm size increase sustainable" model, while the increase volume of the indexes was diverse, depending on the farm and sustainability area. On average, the lowest improvement was made by the partial indexes of economic and social sustainability and the increases in the environmental index were significant at a relative level (from 23\% to 66\%) on individual farms. From the viewpoint of sustainability indexes, effective were also the actions related to the areas of "organisation and management" and even some improvements in "production space quality" were possible (eg. increased content of available phosphorus in the soil).

The changes in the values of sustainability indexes resulting from the activities assumed in individual solutions of the farm optimisation model are presented on the example of farm $E$ (fig. 3). It is a family farm with the area of $43 \mathrm{ha}$, oriented towards dairy production (19 cows) and fattening of young slaughter cattle. Cereals (63\%) dominate the cropping structure. The farm can be described as that of average intensity.

The graphical representation of the sustainability indicator assessment results (fig. 3) allows to trace the values of 56 individual variables taken into account as presented in the table 1 (variables 1-12 - economic sustainability, 13-24 - social sustainability, 25-36 - environmental sustainability, 37-48 - organisation and management, 49-56 - production space quality). It also constitutes a visualisation of the indicator value changes in successive stages of farm modelling. The filling of the chart signifies improvement in individual parameters of the calculation and growing sustainability indicators.

The main conclusion derived from these simulations is the high possibility of a significant sustainability level improvement on the analysed farms. This concerns every sustainability area and all farms, even those with a high initial sustainability index, as it is obvious that the lower the sustainability index in the base model, the higher the potential for its improvement. As shown in the example of the analysed farms, this can be often performed with an insignificant increase of production costs and increase of investment expenditures not exceeding the financing abilities of the farms. Simultaneously, it is possible to achieve significant effects in other sustainability areas with no economic damage.

\section{Closing remarks}

The construction of the sustainability indicator presented in this paper may entail some notes and doubts, which also affected the author. The selection of variables for calculations and their qualification for description of individual sustainability areas is debatable. As far as the selection of variables is concerned, it is a certain compromise between the attempt of full explanation of the analysed phenomena, and the evaluation of the subjective significance of individual variables and technical possibilities of their assessment through interviews with farmers.

However, this does not change the potential applications of the sustainability index calculation at the farm level. This calculation can constitute an analytical tool serving to determine the influence of various changes to the organisation of farms with consideration of their long-term development perspective, simultaneously indicating the sustainability

Table 6 Synthetic Farm Sustainability Index for selected farms corrected according to different model solutions

\begin{tabular}{|c|c|c|c|c|c|c|c|}
\hline \multirow[t]{2}{*}{ Variant of the model* } & \multicolumn{7}{|c|}{ Farm } \\
\hline & A & B & C & D & E & $\mathbf{F}$ & G \\
\hline Base & 0.41 & 0.50 & 0.54 & 0.49 & 0.59 & 0.70 & 0.72 \\
\hline Base „sustainable" & 0.61 & 0.69 & 0.71 & 0.70 & 0.75 & 0.78 & 0.84 \\
\hline Intensive „sustainable & 0.62 & 0.69 & 0.73 & 0.71 & 0.77 & 0.80 & 0.84 \\
\hline Farm size increase „sustainable” & 0.65 & 0.70 & 0.73 & 0.73 & 0.79 & 0.81 & 0.84 \\
\hline Base $=100 \%$ & $156 \%$ & $139 \%$ & $135 \%$ & $148 \%$ & $133 \%$ & $116 \%$ & $118 \%$ \\
\hline
\end{tabular}

* "sustainable" - taking into account environmental constraints in the optimization model and other activities allowing for improving environmental and social sustainability," intensive" assuming productivity increasing additional inputs, ,Ifarm size increase" - enlarging farm area up to $20 \%$ of agricultural land in the base year Source: Own research 
Base

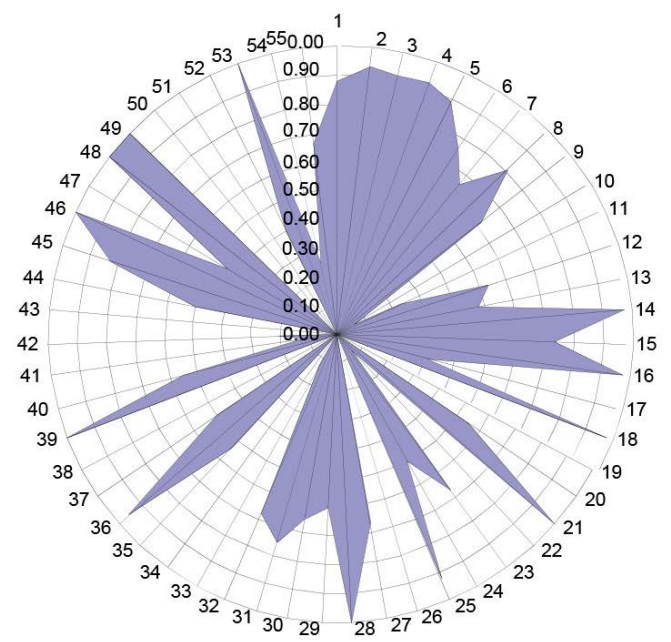

Intensive sustainable

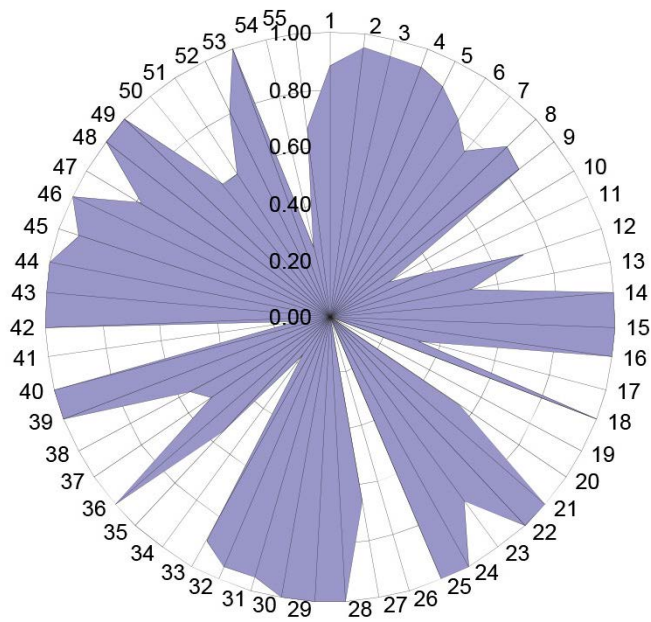

Base sustainable

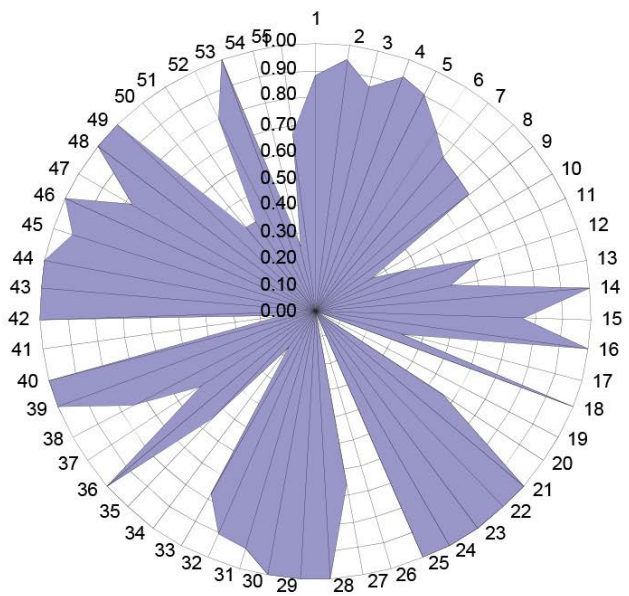

Scale increase sustainable

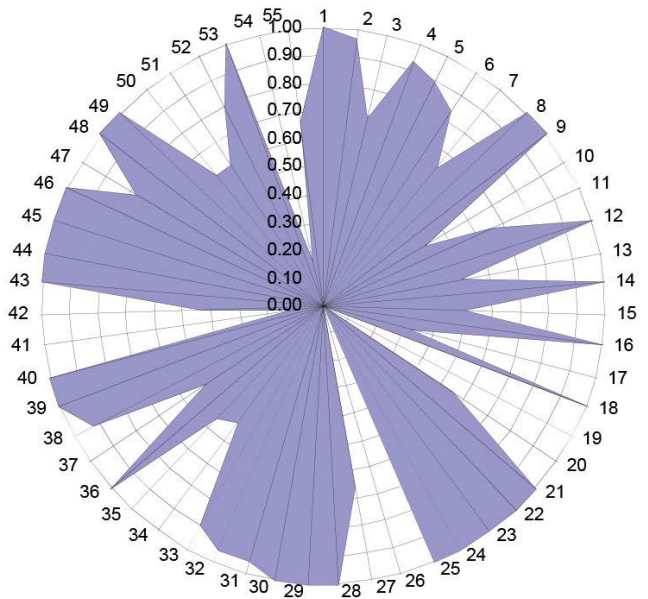

Figure 3 Changes in the value of sustainability indicators in model solutions (farm E) Source: Own calculations

areas requiring particular improvement. This entails signals for the farmers, but also for agricultural advisors, science and decision-makers forming the agricultural, social and environmental policy for agriculture and rural areas. With some possible modifications, the presented approach can finally constitute valuable support in educational and training activities. The determination of the farm sustainability index, with a considerably valuable visualisation of the effects of various changes to the organisation of the farms, should make it easier to comprehend the relations in the complex system of the farm from the perspective of its sustainability, and simultaneously assist in the popularisation of the Sustainable Agriculture and Sustainable Development concepts.

It should be noted that it is practically impossible to achieve an ideal "sustainability" at a level equal to "1", regardless of the method applied in the calculation, which assumes the relativity of the estimation of individual sustainability parameters in the entire sample of analysed objects, or low probability of the occurrence of such natural conditions that would allow the assessment of the maximum level of "production space quality". It should also be emphasized that there are competitive relations among the individual parameters within and across various sustainability areas. For example, investments increasing the value of fixed assets in farms increase the economic sustainability indicator, also because of a potential reduction in the consumption of sustainable means, but in short-term, they influence the reduction of economic sustainability by increasing the farm's debt. In turn, many actions potentially increasing sustainability in sustainability areas other than economic may reduce economic sustainability, regardless of the potentially positive influence of such actions on production and economic results.

An important conclusion from the analysis of the SFSI for the sample of farms is that, in contrasts with a common stereotype on the "environmental friendliness" of traditional, low-input and small farms, large-scale and of high intensity farms can be not only economically viable, but also, environmentally friendly" and, in general, highly sustainable if properly managed.

\section{References}

ANIELSKI, M. - SOSKOLNE, C. L. 2002. Genuine Progress Indicator (GPI) Accounting: Relating Ecological Integrity to Human Heath and Well-being. In: "Just Ecological Integrity: The Ethics of Maintaining Planetary Life", ed. P. Miller I L. Westra, Rowman\&Littlefield Publishers Ltd. 
BOCKSTALLER, C. - GUICHARD, L. - KEICHINGER, 0. - GIRARDIN, P. - GALAN, M. GAILLARD, G. 2009. Comparison of methods to assess the sustainability of agricultural systems. In: Agron. Sustain. Dev., 29, 2009, p. 223-235

BORYS, T. 1999. Wskaźniki Ekorozwoju. In: Wyd. Ekonomia i Środowisko, Białystok, 1999.

CALKER VAN, K. J. 2005. Sustainability of Dutch dairy farming. A modeling approach. Wageningen University.

COBB, C. - HALSTEAD, T. - ROWE, J. 1995. The Genuine Progress Indicator: Summary of Data and Methodology. Redefining Progress, San Francisco.

CRISTOIU, A. 2005. Dimensions of Farming Systems Sustainability in the new Member States. Presentation for the seminar "CAP reforms in New Member States", IPTS Seville, 26. 9. 2005. ftp://ftp.jrc.es/pub/sustag/

DARNHOFER, I. - FAIRWEATHER, J. - MOLLER, H. 2010. Assessing a farm's sustainability: insights from resilience thinking. In: International Journal of Agricultural Sustainability, vol. 8, 2010, no. 3.

DIRECTIONS TOWARDS sustainable agriculture. 1999. Communication from the Commission to the Council, the European Parliament, the Economic and Social Committee and the Committee of the Regions. Commision of the European communities, Brussels, 27. 1. 1999. COM (1999) 22 final

THE WORLD BANK. 2004. Environment at a Glance. The World Bank, Environment Department.

ESTY, D. C. - LEVY, M. A. - SREBOTNJAK, T. - DE SHERBININ, A. - KIM, C. H. - ANDERSON, B. 2006. Pilot 2006. Environmental Performance Index. Yale Center for Environmental Law\&Policy, Yale University, New Haven. www.yale.edu/epi.

ESTY, D. - BOYD, J. 2006. Worldwide Environmental Rankings: Will Nations Compete to Be Green? Resources 161, Spring 2006.

EUROSTAT. 2010. Measuring progress towards a more sustainable Europe. Sustainable development indicators for the European Union. European Commission, Eurostat

FABER, A. 2001. Wskaźniki proponowane do badań równowagi rozwoju rolnictwa. Fragmenta Agronomica, 2001 (XVIII) NT 1 (69).

FERNANDES LÚCIO ANDRÉ DE, 0. - WOODHOUSE, P. 2008. Family farm sustainability in southern Brazil: An application of agri-environmental indicators. In: Ecological Economics, vol. 66, 2008, no. 2-3.

FRANCIS, C. A. 1990. Sustainable Agriculture, Myths and Realities. In: Journal of Sustainable Agriculture, vol. 1, 1990, no. 1.

GIL, S. - ŚLESZYŃSKI, J. 2000. Wskaźnik trwałego dobrobytu ekonomicznego (ISEW). In: Ekonomista, 2000, no. 5.

HAMILTON, K. - ATKINSON, G. - PEARCE, D. 1997. Genuine Savings as an indicator of sustainability. CSERGE Working Paper GEC 97-03.

HAMILTON, K. 2003. Accounting for Sustainability. The World Bank. Handbook of National Accounting, 2003. Integrated Economic and Environmental Accounting 2003. United Nations, Studies and Methods, Series F, no. 61, Rev. 1.

HILL, B. 2004. The reform of the CAP and the economic sustainability of farms issues flowing from agriculture's complex institutional structure and their associated research needs. Seminar materials "Sustainability of agriculture in the enlarged Europe under reformed CAP". Institute for Prospective Technological Studies, DG JRC European Commission, Seville 23-24, 2004

HOWLETT, D. J. B. 1996. Development of social, economic and biophysical indicators for sustainable land management in the South Pacific. W"Sustainable Land Management in the South Pacific. Dowlett D. (ed.), Network Document no 19. International Board for Soil Research and Management, Bangkok, Thailand: IBSRAM.

HUDGENS, R. E. 1992. Selecting Technologies for Sustainable Agriculture. Development Studies Paper Series, Winrock International Institute for Agricultural Development.

LOH, J. (ed.) 2002. Living Planet Report 2002. World Wildlife Fund, 2002. 39 pp.

ŁABĘTOWICZ, J. - MAJEWSKI, E. - RADECKI, A. - KACZOR, A. 2004. Bilans magnezu w wybranych gospodarstwach rolniczych w Polsce. In: Journal of Elementology, vol. 9, 2004, no. 3, p. 367-375.

ŁABĘTOWICZ, J. - MAJEWSKI, E. - RADECKI, A. - KASZCZUK, M. 2002. Bilans fosforu w wybranych gospodarstwach rolnych w Polsce. Nawozy i Nawożenie (Fertilizers and Fertililzation), vol. 13, 2002, no. 4.

MAJEWSKI, E. 2002. Ekonomiczno-organizacyjne uwarunkowania rozwoju Systemu Integrowanej Produkcji Rolniczej (SIPR) w Polsce. Wyd. SGGW, Warszawa.

MAJEWSKI, E. 2008. "Sustainable Development and Sustainable Agriculture - theory and practice of farming”. "Trwały Rozwój i Trwałe Rolnictwo - teoria a praktyka gospodarstw rolniczych". Wyd. SGGW, 2008. pp. 200.

MAJEWSKI, E. - DALTON, G. 2000. Towards strategic changes of the Polish rural economy - agri-food sector in the context of EU accession; "The Strategic options for the Polish Agro-food sector in the light of Economic Analyses". Warsaw : Wyd. Wieś Jutra, 2000.

OECD. 1996. Integrating Environment and the Economy - Progress in the 1990 s. Paris.
OECD. 1997. Environmental Indicators for Agriculture. Concepts and Framework. Paris, vol. 1,1997.

OECD. 1999. Environmental Indicators for Agriculture. Issues and Design The York Workshop, vol. 2, 1999.

OECD. 2001. The OECD Environmental Indicators - Towards Sustainable Development, OECD Paris.

OECD. 2002. Indicators to Measure Decoupling of Environmental Pressure from Economic Growth. SG/SD (2002) 1/FINAL. 108 pp.

OECD. 2003. OECD Environmental Indicators - development, measurement and use (Reference Paper).

OLSSON, J. A. et al. 2004. Indicators for Sustainable Development.

PANNELL, D. J. 2001. What is the Value of a Sustainability Indicator? Economic and Social Issues in Monitoring and Management for Sustainability, SEA Working Paper, 2001, no. 11.

PANNELL, D. J. - SCHILIZZI, S. 1997. Sustainable Agriculture: A Question of Ecology, Equity, Economic Efficiency or Expedience, SEA Working Paper, 1997, no. 1.

PRETTY, J. 1995. Regenerating Agriculture, Earthscan, London.

PRETTY, J. - HOWES, R. Sustainable Agriculture in Britain: Recent Achievements and New Policy Challenges. IIED London, Research Series, vol. 2, no. 1, pp. 74.

PROCHOWICZ, R. - ŚLESZYŃSKI, J. 2006. Wskaźnik trwałego dobrobytu ekonomicznego. Wiadomości Statystyczne, no. 7/8.

RIGBY, D. - HOWLETT, D. - WOODHOUSE, P. 2000a. A Review of Indicators of Agricultural Livelihood Sustainability. Working Paper 1, w Sustainability Indicators for Natural Resource Management and Policy. Centre for Agricultural Food and Resource Economics (CAFRE), University of Manchester.

RIGBY, D. - HOWLETT, D. - WOODHOUSE, P. 2000b. A Review of Indicators of Agricultural Livelihood Sustainability. Working Paper 2, w Sustainability Indicators for Natural Resource Management and Policy. Centre for Agricultural Food and Resource Economics (CAFRE), University of Manchester.

RUNOWSKI, H. 2007. Poszukiwanie równowagi ekonomiczno-ekologicznej i etycznej w produkcji mleka. RNR, seria G. In: Ekonomika Rolnictwa, t. 93, z. 2

THOMSON, K. - SNADDEN, A. 2001. Scottish Parliament Rural Development Committee Study: Developing a framework for assessing the contribution to rural sustainability of public policy in support of agriculture, University of Aberdeen, 2001.

TOWARDS ENVIRONMENTAL PRESSURE INDICATORS FOR THE EU. 1999. European Commission, Eurostat.

UN COMMISSION ON SUSTAINABLE DEVELOPMENT. 2001. Indicators of Sustainable Develop-ment: Guidelines and Methodologies. http://www.un.org/esa/sustdev/ publications/indisd-mg2001.pdf

VENETOULIS, J. - COBB, C. 2004. The Genuine Progress Indicator 1950-2002 (2004 Update). Redefining Progress, San Francisco. www.RedefiningProgress.org.

WACKERNAGEL, M. - REES, W. 1996. Our Ecological Footprint. Reducing Human Impact on the Earth. Gabriola Island, BC, New Society Publishers.

WERF VAN DER, H. - PETIT, J. 2002. Evaluation of the environmental impact of agriculture at the farm level: a comparison and analysis of 12 indicator-based methods. In: Agriculture, Ecosystems \& Environment, vol. 93, 2002, no. 1-3.

WIJNANDS, F. G. - VEREIJKEN, P. 1992. Region-wise development of prototypes if integrated arable farming and outdoor horticulture. In: Netherlands Journal of Agricultural Science, vol. 40, 1992, no. 3, p. 225-238.

WITEK, T. 1993. Waloryzacja rolniczej przestrzeni produkcyjnej według gmin - suplement IUNG Puławy.

WCED (World Commission on Environment and Development). 1987. Our Common Future. Ofxord University Press and United Nations, New York.

World ECONOMIC FORUM. 2002. Environmental Sustainability Index. An Initiative of the WRI (2003): World Resources 2002-2004. Decisions for the Earth.

\section{Contact address:}

Edward Majewski, Warsaw University of Life Sciences, Polland, e-mail: edward_majewski@sggw.pl 